\title{
IKLIM KESELAMATAN KERJA PADA PROYEK KONSTRUKSI DI SURABAYA
}

\author{
Diah Listyaningsih" ${ }^{1)}$ dan Feri Harianto ${ }^{1)}$ \\ 1) Jurusan Teknik Sipil, Institut Teknologi Adhi Tama Surabaya, Jawa Timur \\ diahlistya@itats.ac.id
}

\begin{abstract}
One measure of global competition in the construction sector is the low accident rate (zero accident). To realize this, a conducive work safety climate is needed. Work safety climate can be realized needed occupational safety and health management and workforce support. This study aims to evaluate the work safety climate. Sampling was used a purposive sampling method with a work safety climate measurement tool in the form of a questionnaire based on NOSACQ-50 consisting of 7 dimensions, with analysis using a descriptive frequency test, Mann Whitney, and Chi-Square. The results showed that the three projects studied had a good safety climate, besides there were differences in management's safety priorities. The other dimensions, that are the dimensions of developing work safety management, fairness to work safety management, commitment to employee safety, employee safety priorities and the attitude of not wanting to risk work safety, communication and safety training including trusting in peer safety, competence, and worker's confidence in the work safety system shows that there is no difference. Chi-square test shows that there is no relationship between safety climate with education level, age level and years of service.
\end{abstract}

Keywords: Chi-square Test, Mann Whitney Test, NOSACQ-50, Safety Climate 


\begin{abstract}
ABSTRAK
Salah satu ukuran persaingan global di sektor konstruksi adalah tingkat kecelakaan kerja yang rendah (zero accident). Untuk mewujudkan hal tersebut dibutuhkan iklim keselamatan kerja yang kondusif. Dalam mewujudkannya dibutuhkan manajemen keselamatan dan kesehatan kerja serta dukungan tenaga kerja. Penelitian ini bertujuan untuk mengevaluasi iklim keselamatan kerja. Pengambilan sampel digunakan metode purposive sampling dengan alat ukur iklim keselamatan kerja berupa kuesioner yang didasarkan pada NOSACQ-50 yang terdiri dari 7 dimensi, dengan analisis menggunakan uji deskriptif frekuensi, Mann Whitney dan Chi-Square. Hasil penelitian menunjukkan bahwa ketiga proyek yang diteliti mempunyai iklim keselamatan yang baik, selain itu terdapat perbedaan prioritas keselamatan kerja manajemen. Dimensi lainnya yaitu dimensi pengembangan keselamatan kerja manajemen, keadilan terhadap keselamatan kerja manajemen, komitmen keselamatan kerja karyawan, prioritas keselamatan kerja karyawan dan sikap tidak ingin ambil risiko keselamatan kerja, komunikasi dan pelatihan keselamatan kerja termasuk percaya terhadap kompetensi keselamatan kerja rekan, dan kepercayaan pekerja dalam sistem keselamatan kerja menunjukkan hasil bahwa tidak terdapat perbedaan. Pada uji Chi-square menunjukkan tidak terdapat hubungan antara iklim keselamatan dengan tingkat pendidikan, tingkat usia dan masa kerja.
\end{abstract}

Kata kunci: Uji Chi Square, Uji Mann Whitney, NOSACQ-50, Iklim Keselamatan Kerja 


\section{PENDAHULUAN}

Pembangunan proyek konstruksi merupakan salah satu kegiatan yang mempunyai dampak positif terhadap penyerapan tenaga kerja. Di sisi lain kegiatan konstruksi selalu mempunyai risiko yang cukup tinggi untuk terjadinya kecelakaan kerja. Apabila risiko tersebut tidak dicegah maka akan menimbulkan kerugian yang cukup besar dalam perusahaaan maupun stakeholder yang berkaitan. Dalam langkah pencegahan kerugian dari proyek konstruksi, K3 diperlukan untuk mengatur dan dapat menjadi acuan bagi pelaksana dan para pekerja konstruksi.

Faktor yang menyebabkan terjadinya kecelakaan kerja yaitu faktor manusia dan faktor lingkungan (Suma'mur, 2009). Salah satu faktor yang menyebabkan kecelakaan kerja adalah disiplin yang kurang pada para tenaga kerja untuk mematuhi ketentuan tentang K3 terutama pemakaian alat pelindung diri (APD). Kerugian yang ditimbulkan oleh kecelakaan kerja bukan hanya kerugian secara materi namun juga fisik, kerusakan alat atau bahkan mengakibatkan kematian (Winarsunu, 2008).

Di Kota Surabaya masih banyak terjadi pelanggaran keselamatan dan kesehatan kerja yang dibuktikan dengan jumlah kasus kecelakaan kerja yang masih relatif tinggi. Kurangnya pemakaian APD juga masih sering terjadi serta fasilitas proyek juga masih ada beberapa yang belum layak (Priyono \& Harianto, 2019).

Penelitian pada Proyek Jalan Tol Surabaya-Mojokerto Seksi 1B dihasilkan bahwa variabel yang paling berpengaruh terhadap iklim keselamatan kerja adalah komunikasi (Sutrisno, Sandora, \& Rachman, 2000). Komunikasi memang sangat penting dilakukan supaya apa yang harus dipatuhi di dalam suatu proyek oleh para pekerja dimengerti dengan baik dan harapannya adalah dapat dilaksanakan dengan tepat oleh para tenaga kerja yang terlibat. Penelitian lain di Kota Surabaya yang dilakukan pada 3 proyek pembangunan gedung mengacu pada Health Safety Climate Survey Tools (HSCST), menghasilkan faktor-faktor yang mempengaruhi perbedaan penerapan Sistem Manajemen Keselamatan dan Kesehatan Kerja (SMK3), diantaranya faktor perencanaan, faktor perusahaan kontraktor, faktor kesiapan manajemen, faktor kesadaran manajemen (Priyono \& Harianto, 2019).

Pentingnya kesadaran akan iklim keselamatan kerja menjadi tantangan yang harus selalu disampaikan kepada para pekerja. Tentunya tidak hanya sekedar 
disampaikan, tetapi supaya dijalankan dengan baik. Penelitian meneliti tentang hubungan jumlah data kecelakaan kerja dengan iklim keselamatan kerja (Sukapto, Djojosubroto, \& Bonita, 2016). Dari penelitian tersebut menghasilkansolusi yang dalat dilakukan untuk memperbaiki kondisi iklim keselamatan kerja perusahaan. Oleh karena itu, studi tentang iklim keselamatan kerja pada proyek gedung juga perlu diteliti, supaya para stakeholder yang terlibat mengerti dan peduli akan pentingnya keselamatan kerja serta akan mengurangi tingkat kecelakaan kerja yang terjadi.

\section{KAJIAN PUSTAKA}

Perilaku keselamatan membawa pengaruh terhadap kepatuhan aturan keselamatan yang disebut iklim keselamatan. Iklim keselamatan adalah persepsi mengenai prosedur, dan praktik kerja yang terkait keselamatan. Dalam tingkat yang luas, iklim keselamatan merupakan persepsi pekerja terhadap nilai keselamatan kerja (Prihatiningsih \& Sugiyanto, 2010). Hal lain dikemukakan bahwa secara bersama-sama variable kelesematan kerja dengan kepatuhan berpengaruh terhadap variabel kecelakaan kerja, artinya tidak hanya faktor kepatuhan saja yang mempengaruhi keselamatan kerja, akan tetapi diduga masih ada factor lain yang mempengaruhinya (Sari, 2014).

Pengukuran Iklim keselamatan kerja yang dilakukan pada sector konstruksi salah satunya sudah diteliti dengan menggunakan pengukuran multilevel, dalam sebuah organisasi konstruksi. Hasilnya disebutkan bahwa, dalam organisasi yang diteliti, hasilnya memuaskan karena sebagian besar tenaga kerja, kontraktor, klien, dan stakeholder lain yang terlibat mematuhi peraturan keselamatan yang dianjurkan (Zhang, Lingard, \& Nevin, 2015).

Selain itu, praktek kerja yang didukung oleh komitmen pekerja yang tinggi terhadap keselamatan juga merupakan driver penting untuk iklim keselamatan (Stackhouse \& Turner, 2019). Kepemimpinan, perilaku mematuhi prosedur K3, motivasi keselamatan kerja juga berpengaruh positif terhadap perilaku keselamatan kerja, yang dipengaruhi oleh iklim keselamatan kerja (Huda, Sukmawati, \& Sumertajaya, 2016).

Hubungan antara iklim keselamatan terhadap kecelakaan kerja dimodelkan dan didapatkan hasil bahwa kecelakaan yang paling banyak terjadi pada pembangunan proyek kapal adalah pada saat memegang atau mengangkat material dan peralatan (Mulyasari, 2013). Dalam penelitian lain disebutkan bahwa iklim keselamatan kerja 
dan kepribadian big five personality secara positif berpengaruh terhadap perilaku keselamatan pekerja. Dimana, big five personality diukur menggunakan 5 dimensi, yaitu conscientiousness (hati nurani), negative emotionality (emosi negatif), extraversion (kenyamanan), agreeableness (keramahan), dan openmindedness (pikiran terbuka) (Prabarini \& Suhariadi, 2018).

Untuk mengurangi kecelakaan kerja perusahaan wajib menerapkan iklim keselamatan kerja sebagai acuan untuk menciptakan lingkungan kerja yang aman sebagai bentuk dari promosi budaya keselamatan dan kesehatan kerja di lingkungan kerja (Prasetyo \& Budiati, 2016). Iklim keselamatan kerja yang baik dapat memperkecil jumlah kecelakaan kerja. Oleh karena itu, perlu dilakukannya evaluasi iklim keselamatan kerja pada proyek untuk mengetahui terkait pelaksanaan standar kerja yang berlaku pada proyek tersebut.

Iklim keselamatan sendiri terdiri atas tujuh dimensi yaitu prioritas keselamatan kerja manajemen, pengembangan keselamatan manajemen, keadilan dari manajemen, komitmen dari karyawan, prioritas keselamatan dari karyawan, komunikasi dari rekan dan kepercayaan sistem keselamatan kerja yang diukur menggunakan alat ukur berupa kuesioner NOSACQ-50 yang disebarkan kepada responden yang sudah ditentukan (Kines et al., 2011).

\section{METODE PENELITIAN}

\subsection{Sampel}

Populasi dalam penelitian ini adalah pekerja pada proyek konstruksi gedung di Kota Surabaya. Dari populasi, ditentukan sampel dengan menggunakan metode nonprobability sampling dengan teknik purposive sampling, yakni responden yang dipilih berdasarkan kriteria jabatan, seperti pekerja, tukang, dan mandor. Setelah dilakukan sampling, maka sampel dalam penelitian ini adalah sebanyak 30 responden.

\subsection{Metode}

Metode penelitian yang digunakan adalah metode survey, dengan pengumpulan data melalui kuesioner. Dimana kuesioner disebarkan ke 30 responden pada 3 proyek di Surabaya, kemudian responden melakukan pengisian data dan dikumpulkan kembali untuk dianalisa. Pengukuran pada kuesioner digunakan digunakan skala likert (Sugiyono, 2001). Pembobotan angka 1 untuk sangat tidak setuju, angka 2 untuk tidak setuju, angka 3 untuk setuju, dan angka 4 untuk sangat setuju. Tabel 1 
merupakan lokasi proyek konstruksi gedung yang dijadikan objek penelitian.

Pengambilan data digunakan kuesioner yang kisi-kisinya berpedoman pada NOSACQ-50 yang terdiri dari 50 pertanyaan dan terbagi menjadi 7 dimensi, yaitu: 1) Prioritas keselamatan kerja manajemen, 2) Pengembangan keselamatan kerja manajemen, 3) Keadilan terhadap keselamatan kerja manajemen, 4) Komitmen keselamatan kerja dari para karyawan, 5) Prioritas keselamatan kerja dari karyawan dan sikap tidak ingin ambil risiko keselamatan kerja, 6) Komunikasi dan pelatihan keselamatan kerja termasuk percaya terhadap kompetensi keselamatan kerja dari rekan, dan 7) Kepercayaan pekerja dalam sistem keselamatan kerja.
Pengolahan data dilakukan dengan menggunakan statistik dengan tiga uji. Pertama uji deskriptif frekuensi, yaitu uji yang digunakan untuk memberikan gambaran atau deskripsi suatu data yang diketahui dari nilai mean. Dengan $\mathrm{N}$ adalah jumlah dimensi, maka dari nilai rata-rata (mean) diinterpretasikan kedalam indikator pengukuran seperti Tabel 2. Kedua, Uji Mann Whitney, yaitu uji statistik non parametrik yang bertujuan untuk mengetahui perbedaan dari 2 hasil kelompok yang terdapat pada sampel. Dasar pengambilan keputusannya yaitu: Jika probabilitas $>0.05$ maka $\mathrm{H}_{0}$ diterima, jika probabilitas $<0.05$ maka $\mathrm{H}_{0}$ ditolak, Dengan hipotesis yaitu: $\mathrm{H}_{1}=$ terdapat perbedaan tiap dimensi, sedangkan $\mathrm{H}_{0}=$ tidak terdapat perbedaan tiap dimensi.

Tabel 1. Objek Penelitian

\begin{tabular}{|c|c|c|c|c|c|}
\hline & Nama Proyek & Owner & Konsultan & Kontraktor & Lokasi \\
\hline A & $\begin{array}{l}\text { Apartemen } \\
\text { Belleview }\end{array}$ & $\begin{array}{l}\text { PT. Bumi } \\
\text { Sinar Mas }\end{array}$ & $\begin{array}{l}\text { Cipta Prima } \\
\text { Sejahtera }\end{array}$ & PT. Pulau Intan & $\begin{array}{l}\text { Jl. Manyar } \\
\text { Kertoarjo } 2 \text { No. } \\
78 \text {, Surabaya }\end{array}$ \\
\hline B & $\begin{array}{l}\text { Rumah Sakit } \\
\text { Katolik St } \\
\text { Vincentius } \\
\text { Paulo (RKZ) }\end{array}$ & $\begin{array}{l}\text { Yayasan } \\
\text { Arnoldus }\end{array}$ & $\begin{array}{l}\text { PT. Global } \\
\text { Rancang Selaras }\end{array}$ & $\begin{array}{l}\text { PT. } \\
\text { Multibangunan } \\
\text { Adhitama } \\
\text { Konstruksi } \\
\text { (MULTIKON) }\end{array}$ & $\begin{array}{l}\text { Jl. Diponegoro } \\
\text { No. } 51 \text {, Surabaya }\end{array}$ \\
\hline $\mathrm{C}$ & $\begin{array}{l}\text { Apartemen } \\
\text { Grand } \\
\text { Dharmahusada } \\
\text { Lagoon }\end{array}$ & $\begin{array}{l}\text { PT. PP } \\
\text { Construction } \\
\text { dan } \\
\text { Investment }\end{array}$ & & & $\begin{array}{l}\text { Jl. Mulyosari No } \\
\text { 366A, Mulyorejo } \\
\text { Surabaya }\end{array}$ \\
\hline
\end{tabular}


Tabel 1. Indikator Pengukuran

\begin{tabular}{cc}
\hline Skala & Keterangan \\
\hline $1.00-1.75$ & Sangat Tidak Baik \\
$1.76-2.50$ & Tidak baik \\
$2.60-3.25$ & Baik \\
$3.26-4.00$ & Sangat baik \\
$1.00-1.75$ & Sangat Tidak Baik \\
\hline
\end{tabular}

Ketiga, Uji Chi-Square, yaitu uji statistik non parametrik yang bertujuan untuk mengetahui hubungan atau pengaruh dua buah variabel nominal. Dasar pengambilan keputusannya yaitu: Jika probabilitas > 0.05 maka $\mathrm{H}_{0}$ diterima, jika probabilitas $<0.05$ maka $\mathrm{H}_{0}$ ditolak. Dengan hipotesis berikut: $\mathrm{H}_{1}=$ terdapat hubungan dari dua variabel, sedangkan $\mathrm{H}_{0}=$ tidak terdapat hubungan dari dua variabel.

\section{HASIL DAN PEMBAHASAN}

\subsection{Analisa Deskriptif}

Data responden yang diambil adalah tingkat pendidikan, usia dan lama bekerja responden. Gambar 1a menggambarkan bahwa Responden didominasi oleh lulusan SMA. Lama bekerja responden adalah 6-10 tahun dan usia responden adalah 26 tahun sampai dengan 35 tahun (Gambar 1b). Gambar 1c merupakan diagram responden dilihat dari tingkat pendidikan, usia dan pengalaman Kerja.

Analisis deskriptif frekuensi adalah statistik yang digunakan dalam menganalisis data dengan cara mendeskripsikan data yang telah terkumpul. Analisis ini bertujuan untuk mendeskripsikan data dalam variabel yang dilihat dari nilai rata-rata (mean), minimum, maksimum dan standar deviasi. Hasil evaluasi iklim keselamatan kerja dari ketiga proyek diteliti dapat dilihat pada Tabel 3.

Pada ketiga proyek didapatkan nilai rata-rata (mean) untuk Apartemen Belleview sebesar 2.928, untuk Rumah sakit RKZ sebesar 2.737 dan Apartemen Grand Dharmahusada Lagoon sebesar 2.707. Dari nilai mean tersebut kemudian di interpretasikan kedalam indikator pengukuran pada Tabel 2 sehingga dapat disimpulkan bahwa ketiga proyek masuk dalam kategori baik dengan batasan 2.63.25. Hal ini dapat dibuktikan dengan kondisi lapangan yang sudah menjalankan K3 seperti menggunakan APD, mengadakan briefing sebelum memulai bekerja dan lokasi proyek sudah dilengkapi dengan rambu-rambu K3. 
Tabel 3. Hasil Uji Deskriptif Frekuensi

\begin{tabular}{lcc}
\hline \multicolumn{1}{c}{ Proyek } & N & $\begin{array}{c}\text { Nilai } \\
\text { Rata- } \\
\text { rata }\end{array}$ \\
\hline Apartemen Belleview-Rumah Sakit RKZ & 7 & 2.928 \\
Rumah Sakit RKZ- Apartemen Grand Dharmahusada Lagoon & 7 & 2.737 \\
Apartemen Grand Dharmahusada Lagoon - Apartemen Belleview & 7 & 2.707 \\
\hline
\end{tabular}

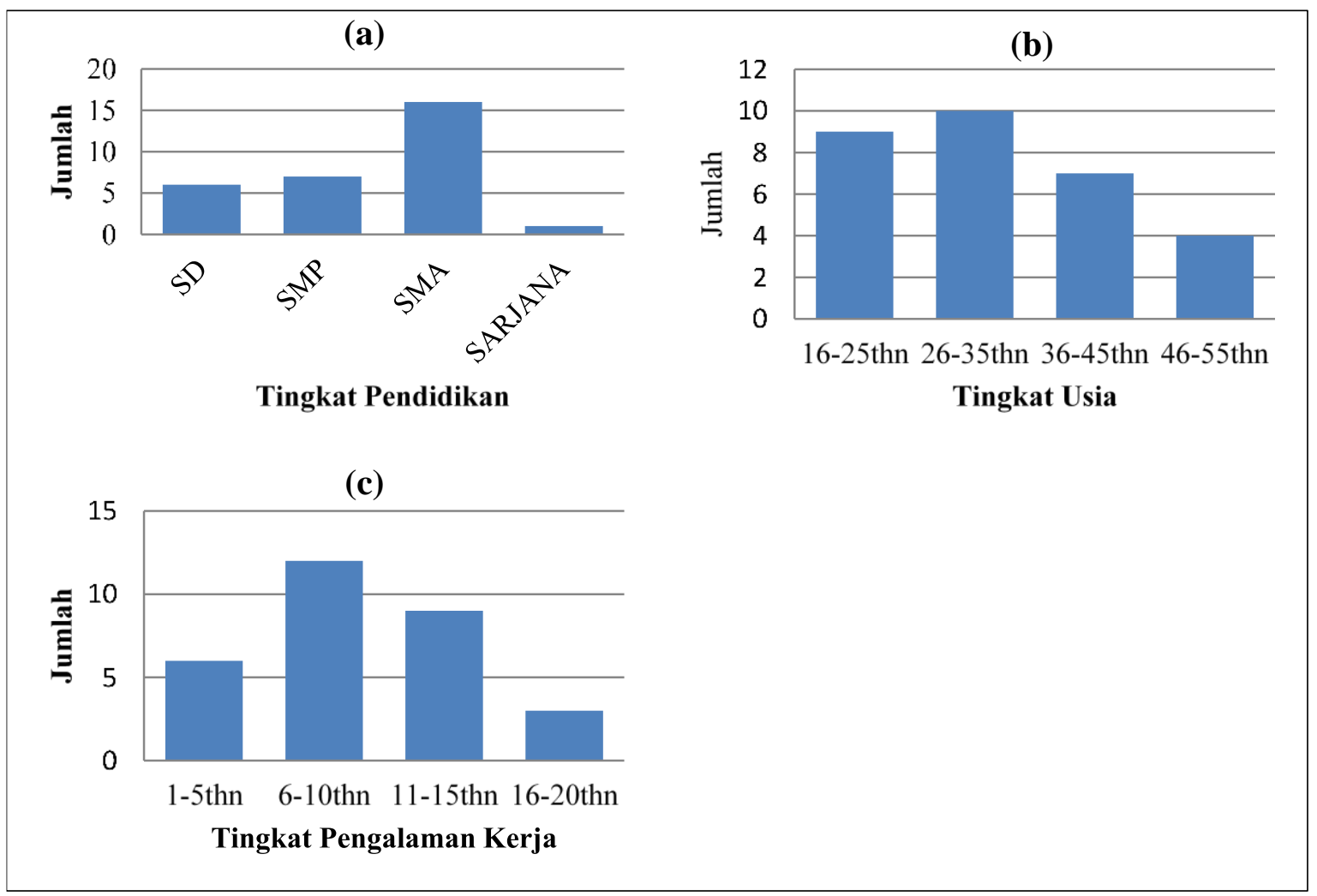

Gambar 1. Diagram Responden

\subsection{Uji Mann Whitney}

\subsubsection{Dimensi Prioritas Keselamatan Kerja Manajemen}

Prioritas keselamatan kerja manajemen merupakan dimensi pertama dalam kuesioner NOSACQ-50. Dimensi ini terdiri dari sembilan pertanyaan yang bertujuan menangkap persepsi pekerja terhadap cara menajemen dalam memprioritaskan Keselamatan.
Nilai asymp. sig dari Apartemen Belleview dan Rumah Sakit RKZ pada dimensi 1 sebesar $0.041<0.05$ maka $\mathrm{H}_{0}$ ditolak sehingga bias dikatakan terdapat perbedaan dimensi ini dari kedua proyek tersebut. Namun diketahui nilai asymp. sig Rumah Sakit RKZ dengan Apartemen Grand Dharmahusada Lagoon sebesar $0.757>0.05$ dan nilai asymp. sig pada Apartemen Grand Dharmahusada Lagoon 
dengan Apartemen Belleview sebesar 0.756

$>0.05$ maka $\mathrm{H}_{0}$ diterima, berarti tidak terdapat perbedaan pada proyek tersebut.

\subsubsection{Dimensi}

Keselamatan

Manajemen

Pengembangan keselamatan kerja dari manajemen bertujuan untuk menangkap persepsi pekerja terhadap manajemen mengenai upaya keselamatan yang telah dilakukan manajemen dalam hal melibatkan pekerja untuk berpartisipasi dalam pengambilan keputusan yang berkaitan dengan keselamatan dan upaya manajemen agar pekerja memiliki kompetensi tinggi berkaitan dengan keselamatan dan risiko. Keterlibatan pekerja dilakukan dengan mengikutsertakan pekerja dalam proses keselamatan.

Dengan tujuh pertanyaan, nilai asymp. sig dari Apartemen Belleview dengan Rumah Sakit RKZ pada dimensi 2 sebesar $0.949>0.05$, pada Rumah Sakit RKZ dengan Apartemen Grand Dharmahusada Lagoon sebesar $0.368>$ 0.05 dan pada Apartemen Grand Dharmahusada Lagoon dengan Apartemen Belleview sebesar $0.140>0.05$ maka $\mathrm{H}_{0}$ diterima, berarti tidak terdapat perbedaan dimensi ini dari ketiga proyek.

\subsubsection{Dimensi Keadilan terhadap Keselamatan Kerja dari Manajemen}

Dimensi ini bertujuan untuk menangkap persepsi pekerja terhadap cara manajemen dalam memperlakukan pekerja yang terlibat kecelakaan, diantaranya apakah manajemen mengumpulkan informasi yang akurat dalam investigasi kecelakaan, memperlakukan pekerja yang terlibat dalam kecelakaan secara adil atau menyalahkan pekerja ketika terjadi kecelakaan. Terdapat enam pertanyaan dalam dimensi ini.

Nilai asymp. sig dari Apartemen Belleview dengan Rumah Sakit RKZ pada dimensi 3 sebesar $0.418>0.05$, pada Rumah Sakit RKZ dengan Apartemen Grand Dharmahusada Lagoon sebesar $0.081>0.05$ dan pada Apartemen Grand Dharmahusada Lagoon dengan Apartemen Belleview sebesar $0.081>0.05$ maka $\mathrm{H}_{0}$ diterima. Hal ini berarti tidak terdapat perbedaan dimensi ini dari ketiga proyek.

\subsubsection{Dimensi Komitmen Keselamatan Kerja Dari Para Pekerja.}

Dimensi ini terdiri dari lima pertanyaan yang menangkap persepsi pekerja tentang bagaimana komitemen terhadap keselamatan kerja, apakah aktif dalam promosi keselamatan kerja dan peduli terhadap keselamatan orang lain. 
Nilai asymp. sig dari Apartemen Belleview dengan Rumah Sakit RKZ pada dimensi 4 sebesar $0.203>0.05$, pada Rumah Sakit RKZ dengan Apartemen Grand Dharmahusada Lagoon sebesar $0.207>0.05$ dan pada Apartemen Grand Dharmahusada Lagoon dengan Apartemen Belleview sebesar $0.748>0.05$ maka $\mathrm{H}_{0}$ diterima. Hal ini berarti tidak terdapat perbedaan dimensi ini dari ketiga proyek.

\subsubsection{Dimensi Prioritas Keselamatan Kerja Dari Pekerja Dan Sikap Tidak Ingin Ambil Risiko Keselamatan Kerja}

Dimensi ini terdiri dari lima pertanyaan yang menangkap persepsi pekerja tentang bagaimana mereka berkaitan dengan keselamatan kerja dalam hal apakah mereka pada umumnya memprioritaskan keselamatan diatas target pekerjaan, tidak menerima kondisi berisiko atau tidak mengambil risiko dan tidak menunjukkan keberanian yang bertentangan dengan aspek keselamatan.

Nilai asymp. sig dari Apartemen Belleview dengan Rumah Sakit RKZ pada dimensi 5 sebesar $0.833>0.05$, pada Rumah Sakit RKZ dengan Apartemen Grand Dharmahusada Lagoon sebesar $0.347>$ 0.05 dan pada Apartemen Grand Dharmahusada Lagoon dengan Apartemen Belleview sebesar 0.402>0.05 maka $\mathrm{H}_{0}$ diterima. Hal ini berarti tidak terdapat perbedaan dimensi ini dari ketiga proyek.

\subsubsection{Dimensi Komunikasi Dan Pelatihan Keselamatan Kerja Termasuk Percaya Terhadap Kompetensi Keselamatan Kerja Dari Rekan}

Dimensi ini menangkap persepsi pekerja tentang bagaimana mereka berkaitan dengan keselamatan ditempat kerja dalam hal berdiskusi mengenai isu-isu keselamatan, belajar dari pengalaman kerja, menolong satu sama lain untuk dapat bekerja secara aman, menerima masukan terkait keselamatan dengan baik dan percaya terhadap kemampuan satu sama lain dalam menjamin keselamatan saat bekerja.

Dengan tujuh pertanyaan nilai asymp. sig dari Apartemen Belleview dengan Rumah Sakit RKZ pada dimensi 6 sebesar $0.404>0.05$, pada Rumah Sakit RKZ dengan Apartemen Grand Dharmahusada Lagoon sebesar $0.336>0.05$ dan pada Apartemen Grand Dharmahusada Lagoon dengan Apartemen Belleview sebesar 0.082 > 0.05 maka $\mathrm{H}_{0}$ diterima, hal ini berarti tidak terdapat perbedaan dimensi ini dari ketiga proyek.

\subsubsection{Dimensi Kepercayaan Pekerja Dalam Sistem Keselamatan Kerja \\ Dimensi ini menangkap persepsi tentang bagaimana mereka dalam melihat keefektifan audit keselamatan, manfaat dari}


perencanaan risiko, manfaat dari pelatihan dari sistem keselamatan kerja yang berjalan dan manfaat dari sasaran dan tujuan keselamatan yang jelas. Dalam dimensi ini terdapat sebelas pertanyaan yang diberikan.

Nilai asymp. sig dari Apartemen Belleview dengan Rumah Sakit RKZ pada dimensi 7 sebesar $0.598>0.05$, pada Rumah Sakit RKZ dengan Apartemen
Grand Dharmahusada Lagoon sebesar $0.223>0.05$ dan pada Apartemen Grand Dharmahusada Lagoon dengan Apartemen Belleview sebesar $0.129>0.05$ maka $\mathrm{H}_{0}$ diterima, hal ini berarti tidak terdapat perbedaan dimensi ini dari ketiga proyek. Secara keseluruhan hasil uji perbedaan dimensi dijabarkan pada Tabel 4.

Tabel 4. Hasil Uji Perbedaan Dimensi

\begin{tabular}{|c|c|c|c|c|}
\hline \multirow{2}{*}{ DimensiDimensi } & \multirow{2}{*}{$\mathrm{NN}$} & \multicolumn{3}{|c|}{$\begin{array}{l}\text { Hasil Uji Mann WhitheyHasil Uji } \\
\text { Mann Whithey }\end{array}$} \\
\hline & & Proyek A & Proyek B & Proyek C \\
\hline Prioritas Keselamatan Kerja Manajemen & 9 & 0.041 & 0.757 & 0.756 \\
\hline Pengembangan Keselamatan Kerja dari Manajemen & 7 & 0.949 & 0.368 & 0.140 \\
\hline $\begin{array}{l}\text { Keadilan Terhadap Keselamatan Kerja dari } \\
\text { Manajemen }\end{array}$ & 6 & 0.418 & 0.081 & 0.081 \\
\hline Komitmen Keselamatan Kerja dari Para Pekerja & 5 & 0.203 & 0.207 & 0.748 \\
\hline $\begin{array}{l}\text { Prioritas Keselamatan Kerja dari Pekerja dan Sikap } \\
\text { Tidak Ingin Ambil Risiko Keselamatan Kerja }\end{array}$ & 5 & 0.833 & 0.347 & 0.402 \\
\hline $\begin{array}{l}\text { Komunikasi dan Pelatihan Keselamatan Kerja } \\
\text { Termasuk Percaya Terhadap Kompetensi } \\
\text { Keselamatan Kerja dari Rekan }\end{array}$ & 7 & 0.404 & 0.336 & 0.082 \\
\hline $\begin{array}{l}\text { Kepercayaan Pekerja dalam Sistem Keselamatan } \\
\text { Kerja }\end{array}$ & 11 & 0.598 & 0.223 & 0.129 \\
\hline
\end{tabular}

\subsection{Uji Chi-Square}

Uji chi-square merupakan analisis yang bertujuan untuk mengetahui hubungan antara variabel yang berjenis data kategori atau data frekuensi yaitu hubungan antara tingkat pendidikan, tingkat usia dan masa kerja terhaddap iklim keselamatan kerja. Di bawah ini adalah hasil dari uji chi square yang sudah di analisis. Hasil uji chi-square antara iklim keselamatan dengan tingkat pendidikan seperti pada Tabel 5 .

Berdasarkan Tabel 5 nilai asymp. sig dari tingkat pendidikan dengan iklim keselamatan sebesar $0.085>0.05$, tingkat usia dengan iklim keselamatan memperoleh nilai asymp. sig sebesar $0.297>0.05$ dan masa kerja dengan iklim keselamatan 
memperoleh nilai asymp. sig sebesar 0.374 $>0.05$ maka $\mathrm{H}_{0}$ diterima sehingga dapat dinyatakan bahwa tidak terdapat hubungan iklim keselamatan dengan social demografi yang diteliti. Terdapat beberapa pekerjaan yang tidak terlalu mementingkan pendidikan formal melainkan lebih ke keterampilan, fisik dan skill (Pratama, 2015). Untuk tingkat usia biasanya usia muda cenderung tergesa-gesa dalam bekerja dan usia tua cenderung kekuatan fisiknya menurun, dan untuk masa kerja biasanya semakin lama bekerja maka akan menimbulkan kebiasaan dalam cara bekerja. Maka dapat dikatakan semua tingkatan sosial demografi mempunyai persepsi yang sama mengenai iklim keselamatan Kerja.

Tabel 5. Hasil Hubungan iklim Keselamatan Kerja dengan Sosial Demografi

\begin{tabular}{lc}
\hline \multicolumn{1}{c}{ Parameter } & $\begin{array}{c}\text { Asymp. Sig } \\
\text { (2-tailed) }\end{array}$ \\
\hline Tingkat Pendidikan- Iklim Keselamatan Kerja & 0.085 \\
Tingkat Usia- Iklim Keselamatan Kerja & 0.297 \\
Masa Kerja- Iklim Keselamatan Kerja & 0.374 \\
\hline
\end{tabular}

\section{SIMPULAN DAN SARAN}

Berdasarkan analisis tersebut maka dapat disimpulkan evaluasi iklim keselamatan kerja pada proyek yang diteliti termasuk dalam kategori proyek yang baik. Hal ini ditunjukkan dengan nilai rata-rata pada proyek Apartemen Belleview sebesar 2.92 (baik), pada proyek Rumah Sakit RKZ sebesar 2.73 (baik) dan proyek Apartemen Grand Dharmahusada Lagoon sebesar 2.70 (baik). Hal ini terbukti dalam kondisi di lapangan dimana semua proyek sudah menjalankan K3 seperti ada rambu-rambu $\mathrm{K} 3$, penggunaan $\mathrm{APD}$, dan lain-lain.
Dari ke tujuh dimensi yang dianalisis dapat disimpulkan bahwa terdapat 1 dimensi yang memiliki perbedaan yaitu pada dimensi prioritas keselamatan kerja manajemen antara proyek Apartemen Belleview dengan Rumah Sakit RKZ $(0.041<0.05)$. Sedangkan pada ke enam dimensi yang lain tidak terdapat perbedaan yang signifikan $\alpha>0.05$ ).

Iklim keselamatan kerja tidak memiliki hubungan dengan tingkat pendidikan, usia pekerja maupun masa kerja pada ketiga proyek yang diteliti $(\alpha>5 \%)$. 
Penelitian selanjutnya dapat ditambahkan variable lain, misalnya pada variabel tingkat kesadaran, kepatuhan pekerja dan lain-lain yang berhubungan dengan kondisi dan jenis proyek yang akan diteliti. Penambahan responden jumlah sampel dalam penelitian akan menambah validasi hasil penelitian.

\section{DAFTAR PUSTAKA}

Huda, U. F., Sukmawati, A., \& Sumertajaya, I. M. (2016). Model Perilaku Keselamatan Kerja Karyawan Pada Industri Berisiko Tinggi. Jurnal Manajemen Teknologi, 15(1), 51-66.

Kines, P., Lappalainen, J., Mikkelsen, K. L., Olsen, E., Pousette, A., Tharaldsen, J., ... Törner, M. (2011). Nordic Safety Climate Questionnaire (NOSACQ-50): A new tool for diagnosing occupational safety climate. International Journal of Industrial Ergonomics, 41(6), 634646.

https://doi.org/10.1016/j.ergon.2011. 08.004

Mulyasari, W. (2013). Pengembangan Model Iklim Keselamatan Terhadap Kecelakaan Kerja Dan Penyakit Akibat Kerja (PAK). Prosiding Seminar Nasional Manajemen Teknologi XVIII, 1-9.

Prabarini, P., \& Suhariadi, F. (2018). Iklim Keselamatan Kerja dan Big Five Personality Sebagai Prediktor Perilaku Keselamatan Karyawan. Jurnal Psikologi Teori Dan Terapan, 9(1), 1-16. https://doi.org/10.26740/jptt.v9n1.p1 $-16$
Prasetyo, E., \& Budiati, R. E. (2016). Analisis Program Inspeksi K3 sebagai Bentuk Upaya Promosi Budaya K3 di Lingkungan Kerja. Jurnal Kesehatan Masyarakat, 4(1), $1-8$.

Pratama, A. K. (2015). Hubungan Karakteristik Pekerja Dengan Unsafe Action Pada Tenaga Kerja Bongkar Muat Di Pt. Terminal Petikemas Surabaya. The Indonesian Journal of Occupational Safety and Health, 4(1), 64-73. https://doi.org/10.20473/ijosh.v4i1.2 015.64-73

Prihatiningsih, \& Sugiyanto. (2010). Pengaruh Iklim Keselamatan dan Pengalaman Personal terhadap Kepatuhan pada Peraturan Keselamatan Pekerja Konstruksi. Jurnal Psikologi, 37(1), 82-93.

Priyono, A. F., \& Harianto, F. (2019). Analisis Penerapan Sistem Manajemen K3 dan Kelengkapan Fasilitas K3 Pada Proyek Konstruksi Gedung Di Surabaya. Rekayasa Jurnal Teknik Sipil, 4(2), 11-16.

Sari, R. E. (2014). Evaluasi iklim Keselamatan Kerja dengan Menggunakan Metode NOSACQ-50 di PT. Primarindo Asia Infrastruktur, Tbk. Jurnal Psikologi Mandiri, 8190.

Stackhouse, M., \& Turner, N. (2019). How do organizational practices relate to perceived system safety effectiveness? Perceptions of safety climate and co-worker commitment to safety as workplace safety signals. Journal of Safety Research, 70, 5969.

https://doi.org/10.1016/j.jsr.2019.04. 002

Sugiyono. (2001). Statistika untuk Penelitian. Bandung: Alfabeta. 
Sukapto, P., Djojosubroto, H., \& Bonita. (2016). Evaluasi iklim Keselamatan Kerja dengan Menggunakan Metode NOSACQ-50 di PT. Primarindo Asia Infrastruktur, Tbk. Simposium Nasional RAPI XV, 143-149. Surakarta.

Suma'mur. (2009). Hiegine Perusahaan Dan Kesehatan Kerja. Jakarta: CV. Agung Seto.

Sutrisno, H. Y., Sandora, R., \& Rachman, F. (2000). Pengaruh Iklim Keselamatan Terhadap Perilaku Keselamatan Pada Proyek Tol Surabaya - Mojokerto Seksi 1B. Proceeding 1st Conference on Safety Engineering and Its Application, 1923.

Winarsunu, T. (2008). Psikologi Keselamatan Kerja. Malang: UMM Pers.

Zhang, R. P., Lingard, H., \& Nevin, S. (2015). Development and validation of a multilevel safety climate measurement tool in the construction industry. Construction Management and Economics, 33(10), 818-839. https://doi.org/10.1080/01446193.20 15.1108451 